\title{
Dynamics of microbial growth in surface layers of a coastal marine sediment ecosystem
}

\author{
David M. Karl ${ }^{1}$, James A. Novitsky ${ }^{2}$ \\ ${ }^{1}$ Department of Oceanography and Hawaii Institute of Geophysics, University of Hawaii, Honolulu, Hawaii 96822, USA \\ ${ }^{2}$ Department of Biology, Dalhousie University, Halifax, Nova Scotia, Canada B3H 4J1
}

\begin{abstract}
Growth kinetics of the microbial community of a coastal, sub-tropical sediment were studied by following uptake of ${ }^{3} \mathrm{H}$-adenine. ${ }^{3} \mathrm{H}$-adenine was incorporated into RNA and DNA, thus providing a measure of both cell metabolism and growth. Extrapolation from measured values of isotope dilution of the ATP pool at isotopic equilibrium (i.e. $\mathrm{SA}_{\text {max }}$ parameter) indicated that a large portion of the adenine required for community nucleic acid synthesis was derived from uptake of exogenous supplies. Microbial community doubling times, estimated from adenine nucleotide pool labeling kinetics, ranged from $26 \mathrm{~h}$ at the seawater-sediment interface to 47 to $92 \mathrm{~h}$ for samples beneath the interface. RNA synthesis rate consistently exceeded DNA synthesis rate by 1 to 2 orders of magnitude for all horizons examined, in spite of these relatively slow growth rates. The newly synthesized RNA was found to be stable with less than $10 \%$ being degraded during a period equivalent to the mean population doubling time. Our results indicate a sediment microbial community with growth rates and metabolism distinctly different from water-column communities. The results strongly suggest net, but unbalanced growth in these sediment communities.
\end{abstract}

\section{INTRODUCTION}

Field data on the distribution of microbial (bacteria, microalgae, protozoans) populations in surface marine sediments and on the rates of microbial growth and production are essential to elucidate the mechanisms of organic matter diagenesis and to interpret data on such diverse processes as biogenic gas flux (e.g. $\mathrm{CO}_{2}, \mathrm{CH}_{4}$, $\mathrm{H}_{2}, \mathrm{H}_{2} \mathrm{~S}$ ), rates of nutrient cycling and the distribution of sedimentary metazoan populations. Previous research efforts on the microbial ecology of marine sediments have established that bacteria are very abundant, with typical population densities of $10^{8}$ to

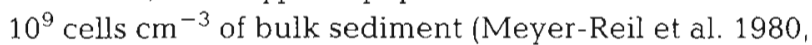
Schroder \& Van Es 1980, Newell \& Fallon 1982, Rublee 1982, Fallon et al. 1983, Novitsky 1983a, b, Rublee et al. 1983. Craven et al. 1986), irrespective of habitat type, latitude or water depth. Consequently, it appears that coastal marine sediments support roughly $10^{3}$ to $10^{4}$ times as many bacteria per unit volume than is typically found in the overlying surface seawater.

A major uncertainty in marine sedimentary microbiology, however, regards the in situ metabolic state of the resident microbial assemblages. If the sedimentary ecosystem is simply comprised of an assemblage of senescent, starved or otherwise debilitated cells, then their cumulative impact on diagenesis might be much less than the contribution from pelagic microbial communities, in spite of high cell numbers and biomass in sediments. Metabolically-active cells can be enumerated by microautoradiography following exposure to a specific radiolabeled organic or inorganic substrate (Karl 1986). Microautoradiography with total cell counts by epifluorescence microscopy permits estimation of the percentage of 'active' cells, at least with respect to a specific substrate. Thus calculated, the percentage of metabolically active bacterial cells in marine sediments exhibits a wide range, from less than $1 \%$ to greater than $95 \%$ of the total population (data summarized in Douglas et al. 1987).

In a previous paper (Novitsky \& Karl 1986), we initially characterized the microbial populations in the surface sediment of Kahana Bay, Hawaii. At our sampling site, we observed an order of magnitude decrease in microbial biomass (as determined by total ATP) between the sediment-water interface and a sediment depth of $5 \mathrm{~cm}$. This depth distribution of ATP was coherent both in space and time (Novitsky \& Karl 1986). The greatest change in microbial biomass was observed between interface layer and topmost sedi- 
ment sample. In spite of this decrease in total microbial biomass, total rate of ${ }^{14} \mathrm{C}$-labeled glutamic acid assimilation was relatively constant. Consequently, cellspecific heterotrophic activity of the population actually increased with increasing sediment depth. We also tested, and then rejected, the hypothesis that metabolic activity (as measured by uptake and respiration of ${ }^{14} \mathrm{C}$ glutamic acid) was coupled to cell growth and division (as measured by ${ }^{3} \mathrm{H}$-adenine incorporation into RNA and DNA, respectively). The present paper extends these preliminary investigations with a more detailed examination of the relationsships among microbial biomass, cell growth and division and nucleic acid synthesis in sediments collected from Kahana Bay, Hawaii.

\section{MATERIALS AND METHODS}

Sampling site, sample collection and subsampling. Sediment samples were collected from Kahana Bay, Oahu, Hawaii at the site studied by Novitsky \& Karl (1986), using hand-operated plastic core tubes, and transported intact to the laboratory (within $-1 \mathrm{~h}$ ) where the experiments were performed. Sediment cores were extruded, sectioned and subsampled following procedures described by Novitsky (1983b) and Novitsky \& Karl (1986). Water samples were collected by hand into acid-washed polycarbonate bottles from a depth of $0.5 \mathrm{~m}$ above the sediment-seawater interface. Average water depth in our study area was ca $1.0 \mathrm{~m}$ (mean low water).

Analytical procedures. For ATP determinations, triplicate $2 \mathrm{~cm}^{3}$ portions of the homogenized sediment samples were immediately injected into $10 \mathrm{ml}$ of cold $1.47 \mathrm{M} \mathrm{H}_{3} \mathrm{PO}_{4}$ and allowed to extract for $15 \mathrm{~min}$, with occasional agitation. Samples were centrifuged $(1500 \times \mathrm{g}, 15 \mathrm{~min})$, and $100 \mu \mathrm{l}$ of the supernatant was diluted into $4.9 \mathrm{ml}$ of phosphate buffer ( $\left.60 \mathrm{~m} M_{1} \mathrm{pH} 7.4\right)$. Samples were immediately assayed for ATP using the firefly bioluminescence reaction (Karl \& Craven 1980). For interface samples, $1 \mathrm{ml}$ of the slurry was pipetted directly into $5 \mathrm{ml}$ of boiling $60 \mathrm{mM}$ phosphate buffer, $1 / 2 \mathrm{ml}$ at a time, and extracted at $100^{\circ} \mathrm{C}$ for $5 \mathrm{~min}$. Internal ATP standards were used to correct for real and apparent losses of extractable ATP.

RNA and DNA synthesis were measured using ${ }^{3} \mathrm{H}$ adenine as described by Novitsky \& Karl (1986). Subsamples of the homogenized sediments were mixed with $0.2 \mu \mathrm{m}$ filtered seawater collected at the Kahana Bay sampling site. Final slurry concentrations ranged from 0.5 to $1 \mathrm{~cm}^{3}$ of sediment per $100 \mathrm{ml}$ seawater (for samples collected from the interface region) to 2.5 to $5.5 \mathrm{~cm}^{3}$ of sediment per $100 \mathrm{ml}$ seawater for samples collected from beneath the interface. As discussed below, rates of ${ }^{3} \mathrm{H}$ adenine metabolism (expressed per unit $g$ of sediment) were independent of sediment-seawater slurry concentration over a wide range of values.

Adenine nucleotide (AN) pool turnover rate measurements were performed according to the procedure of Karl \& Bossard (1985), using ${ }^{3} \mathrm{H}$-adenine (Karl et al. 1987). Collectively these above-mentioned analytical procedures provide information on total microbial biomass, microbial productivity and microbial growth (turnover) rate.

Sediment incubation experiments. The reliability of our incubation procedure for Kahana Bay sediments was evaluated in 2 separate sets of experiments. In the first, we investigated the relation between the extent of sediment dilution and total microbial metabolism of ${ }^{3} \mathrm{H}$ adenine. Subsamples from the bulk sediment core were mixed with filter-sterilized overlying seawater to yield a dilution series covering a ranǵe of ca 100 -fold, from 0.1 to $10 \%$ by volume. Immediately following the dilution procedure, the rate of ${ }^{3} \mathrm{H}$-adenine metabolism was measured over a relatively short-term incubation period $(\sim 1 \mathrm{~h})$. In the second set of experiments, the rate of microbial nucleic acid synthesis was monitored in diluted subsamples of sediment following prolonged incubation periods (up to $18 \mathrm{~h}$ ).

Uptake and assimilation of ${ }^{3} \mathrm{H}$-adenine was a linear function of dilution for sediment-seawater slurries (Fig. 1). Most of the variation in adenine metabolism can be attributed to sediment slurry concentration. We next investigated the reliability of our procedure by diluting subsamples collected from each depth horizon to final concentrations of $4 \%\left(2 \mathrm{~cm}^{-3}\right.$ wet sediment per $50 \mathrm{ml}$ of sterile-filtered water) followed by measuring total rates of microbial RNA and DNA synthesis during a long-term time course incubation (Table 1). We reasoned that if subsampling and dilution procedures

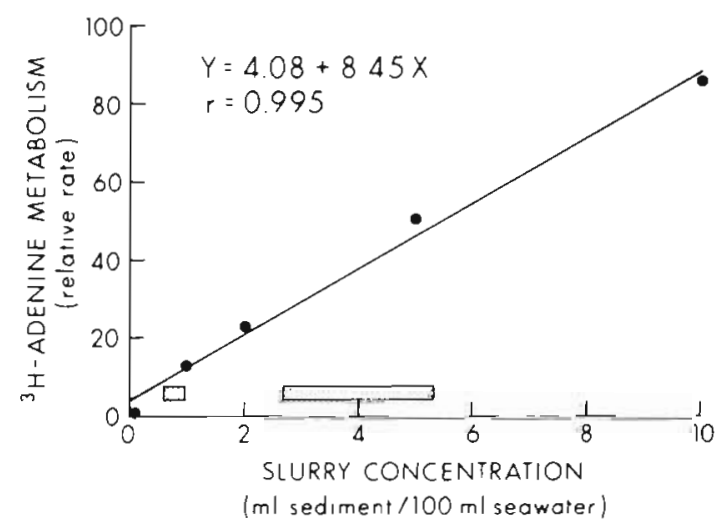

Fig. 1. Relation between sediment slurry concentration and microbial metabolism. Sediment was homogenized and diluted with filter-sterilized overlying seawater. ${ }^{3} \mathrm{H}$-adenine was added to each sample and its metabolism monitored by the production of ${ }^{3} \mathrm{H}_{2} \mathrm{O}$ (Karl 1981). Stippled areas: slurry concentrations used in this study for analysis of interface (left bar) and sediment column (right bar) microbial communities 
themselves had caused either a stimulation or a repression in microbial metabolism, we would have been able to detect the respective change in the measured rates of microbial metabolism. However, neither the rate of RNA nor the rate of DNA synthesis varied significantly during this relatively long-term experiment (Table 1). The experimental results described in the subsequent portions of this paper were all derived from time-course incubations $\leq 4 \mathrm{~h}$ in duration. Thus we feel that the sediment slurry incubation technique described above provides reliable metabolic-rate estimates for microorganisms in Kahana Bay sediments

\section{RESULTS AND DISCUSSION}

\section{Methodological concerns}

Incubation of sediment samples with aqueous radioactive tracers presents an immediate concern with respect to potential experimental treatment artifacts. In the course of our preliminary investigations with marine sediments (Craven \& Karl 1984), it became apparent that radiotracer theory would be reliable only in well-mixed sediment slurries. It is imperative that all microorganisms are exposed to the same external specific radioactivity (i.e. ratio of radioactive substrate to non-radioactive substrate) if one would hope to trace the flux of material through the entire microbial community. Homogenization, however, destroys the normal diffusion-controlled gradients that are characteristic of nearshore marine sediments. To the extent that the disruption of these gradients might also alter the metabolic rates of the resident microbial community, it is essential to determine, independently, the effects of this experimental treatment.

Such an evaluation was accomplished by performing several experiments to monitor the effect of sediment dilution and homogenization on rates of microbial assimilation of ${ }^{3} \mathrm{H}$-adenine. In the first experiment, we established a linear relation between sediment-seawater slurry concentration (i.e. volume of sediment) and microbial activity (Fig. 1). Although this experiment was not designed to evaluate the effect of initial dilution (all samples were relatively dilute compared to the native habitat) we were able to establish the fact that extensive dilution of the sedimentary microbial assemblage did not significantly alter the short-term rates ( $1 \mathrm{~h}$ ) of ${ }^{3} \mathrm{H}$-adenine assimilation, either by stimulation or repression.

A second set of experiments was designed to evaluate the effects of initial disruption of the sedimentary habitat. It is virtually impossible to conduct a direct experiment to monitor this effect because all treatments which involve the injection of a radiotracer (including the negative control with 'no disruption') could potentially cause a change in the microhabitat of the sedimentary ecosystem simply by the manipulation involved in isotope injection. Consequently, we designed an experiment which we felt would provide a satisfactory indirect evaluation of impact of our experimental procedures on the rates of microbial metabolism. Our experimental design relied on the well-established observations of metabolic 'shift-up' and 'shiftdown' of microbial metabolism in response to changes in environmental conditions. If disruption and homogenization of the sediment chemical gradients resulted in a more favorable growth enviromment, the microbial assemblage would shift-up their rate of community metabolism in response to these new conditions. Likewise, if conditions were less favorable for growth and metabolism, a systematic decrease in community ${ }^{3} \mathrm{H}$-adenine assimilation would be observed with time. The kinetics of the shift-up or shift-down in community metabolism are such that the effect should be observed over a period of one to a few hours,

Table 1. Effects of incubation time on the incorporation of ${ }^{3} \mathrm{H}$-adenine into microbial RNA and DNA following sediment sample dilution

\begin{tabular}{|c|c|c|c|c|}
\hline $\begin{array}{l}\text { Experimental } \\
\text { preparation }\end{array}$ & $\begin{array}{l}\text { Time after formation of } \\
\text { sediment slurry (h) }\end{array}$ & \multicolumn{2}{|c|}{$\left(\mathrm{nCi} \mathrm{g}{ }^{-1}\right.$ dry wt $\left.\mathrm{h}^{-1}\right)$} & $\begin{array}{l}\text { DNA: RNA } \\
\text { ratio }\end{array}$ \\
\hline I & 2 & 2577 & 58.9 & 0.023 \\
\hline II & 4 & 1992 & 36.8 & 0.018 \\
\hline II & 8 & 3297 & 46.4 & 0.014 \\
\hline I & 12 & 3276 & 49.7 & 0.015 \\
\hline \multirow[t]{2}{*}{ II } & 18 & 2686 & 46.0 & 0.017 \\
\hline & & $\begin{array}{r}2766^{b} \\
( \pm 544)\end{array}$ & $\begin{array}{r}47.6^{b} \\
( \pm 7.9)\end{array}$ & $\begin{array}{r}0.017^{b} \\
( \pm 0.004)\end{array}$ \\
\hline $\begin{array}{l}\text { a Sediment-seawate } \\
\text { weight } \mathrm{ml}^{-1} \text { for } \mathrm{P} \\
{ }^{\mathrm{b}} \text { Mean of individu }\end{array}$ & $\begin{array}{l}\text { urries used in this experi } \\
\text { rations I and II, respectiv } \\
\text { eterminations }(n=5), \pm 1\end{array}$ & $\begin{array}{l}\text { e } 4.658 \mathrm{mg} \\
\text { e mean in }\end{array}$ & y weight & mg sedime \\
\hline
\end{tabular}


depending upon several uncontrollable variables such as the composition of the microbial community under investigation, the initial growth rate(s), the nature of the growth rate limitation, etc. If, over relatively long time periods, the rate of microbial community metabolism was not altered significantly, then we would conclude that the initial experimental treatment (in this case, sediment homogenization and dilution) had a minimal effect on community growth. Our results indicate that neither the rate of RNA nor DNA synthesis displayed any systematic change over incubation periods ranging from 2 to $18 \mathrm{~h}$ (Table 1 ). On the basis of these 2 sets of experimental results, we conclude that the sediment-seawater slurry short-term incubation technique used in this study did not bias the measured rates of microbial metabolism of ${ }^{3} \mathrm{H}$-adenine. These results may be unique for the Kahana Bay sediments under investigation, but are probably not unique to the uptake and assimilation of ${ }^{3} \mathrm{H}$-adenine.

\section{Production rates}

Rates of total microbial RNA and DNA synthesis estimated by ${ }^{3} \mathrm{H}$-adenine uptake exhibit trends that are consistent with the depth distribution of biomass: namely, high rates of nucleic acid production at the seawater-sediment interface $\left(\mathrm{RNA}\right.$ rate $=4.2 \times 10^{4}$ pmol g ${ }^{-1}$ dry wt h ${ }^{-1}$; DNA rate $=5.5 \times 10^{2} \mathrm{pmol} \mathrm{g}^{-1}$ dry wt $\mathrm{h}^{-1}$ ) and roughly an order of magnitude decrease at a depth of $5 \mathrm{~cm}$ (see Fig. 5 in Novitsky \& Karl 1986). Based on previously published extrapolation factors (Karl \& Winn 1984), these estimates correspond to microbial carbon production rates ranging from 0.82 (interface) to 0.07 ( $5 \mathrm{~cm}$ depth) $\mathrm{mg} \mathrm{C} \mathrm{g}^{-1} \mathrm{sed}^{-1}$, or to a

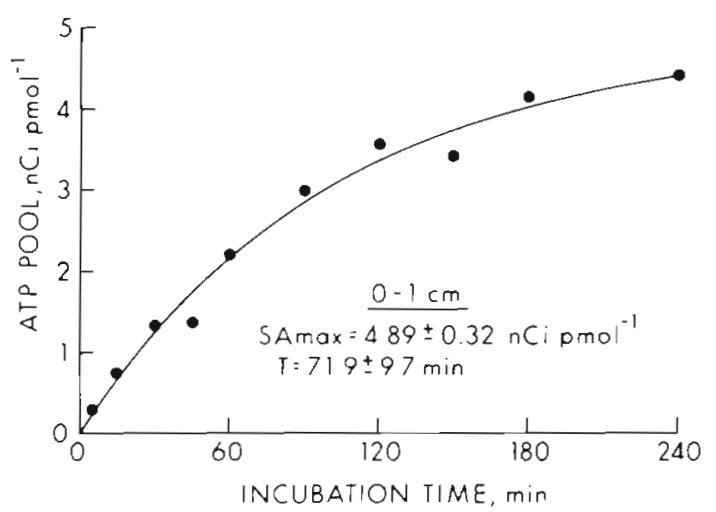

Fig. 2. Representative changes in specific radioactivity ( $\mathrm{nCi}$ pmol $^{-1}$ J of the total sediment microbial population as a function of incubation time following addition of ${ }^{3} \mathrm{H}$-adenine. The estimated specific radioactivity maximum at isotopic equilibrium ( $\mathrm{SA}_{\mathrm{max}}$ ), estimated turnover time of the ATP pool (T), and their respective $95 \%$ confidence intervals were calculated by non-linear least squares regression using the model equation for exponential labeling (Karl et al. 1987)
0 to $5 \mathrm{~cm}$ depth-integrated production of $\mathrm{ca} 22 \mathrm{~g} \mathrm{C}$ $\mathrm{m}^{-2} \mathrm{~d}^{-1}$. By comparison, the total microbial production rate for the overlying water column was ca $1 \mathrm{~g} \mathrm{C}$ $\mathrm{m}^{-2} \mathrm{~d}^{-1}$. Clearly, the sediment habitat is the major contributor $(>95 \%)$ to total ecosystem productivity at this site. Because these sediments receive little light energy, we believe that the majority of this production is heterotrophic, ultimately supported by allochthonous carbon derived from terrigenous sources. An equally interesting observation is the fact that the specific rate of nucleic acid synthesis (i.e. the rate per unit ATP biomass) is generally invariant with depth (RNA rate $=$ 6 to $12 \mathrm{nmol} \mathrm{ng} \mathrm{ATP}^{-1} \mathrm{~h}^{-1}$; DNA rate $=0.20$ to 0.32 nmol ng $\mathrm{ATP}^{-1} \mathrm{~h}^{-1}$ ). Consequently, one cannot view the deep, biomass-poor region of the sediment as an unfavorable habitat for microbial growth or production. On a per cell biomass basis, the rates of nucleic acid synthesis are comparable to those measured in the biomass-rich interface region.

\section{Adenine nucleotide pool turnover}

In the present study we measured the adenine nucleotide (AN) pool turnover rate as an independent estimate of community doubling time (Karl \& Bossard 1985, Karl et al. 1987). This method requires a time course incubation to monitor the rate at which the intracellular AN pool is labeled as it approaches isotopic equilibrium (Fig. 2). The analysis of these data provides: (1) a direct measure of the pool turnover rate, which is proportional to the mean microbial community doubling time; (2) an estimate of the AN pool at isotopic equilibrium (Karl et al. 1987). There are several important features of these results which warrant discussion. First, the community doubling times derived from these time course incubations indicate a value of ca 1 doubling per day for the interface sample and a value of 0.25 to 0.5 doublings per day for the deeper sediment samples (Table 2). Beneath the interface zone, there is no systematic change with sediment depth.

Additional ecological information can also be derived from the AN pool turnover experiments. The specific activity value of the $A N$ pool at isotopic equilibrium (i.e. $\mathrm{SA}_{\max }$ Fig. 2 and Table 2) can be used as a direct measure of the capacity of a given population to salvage exogenous nucleic acid precursors in favor of de novo synthesis. In theory, $\mathrm{SA}_{\text {nax }}$ will be influenced by the external specific activity of the introduced precursor and by internal dilution resulting from de novo synthesis. Because all of the sediment slurries were prepared with the same sterile-filtered, near-bottom seawater, the external specific activity for all of our incubations in a given experiment would be identical. If the introduced ${ }^{3} \mathrm{H}$-adenine is diluted neither by external nor internal 
Table 2. Adenine nucleotide pool turnover rates and derived parameters for sedimentary microbial populations from Kahana Bay

\begin{tabular}{|c|c|c|c|c|}
\hline $\begin{array}{l}\text { Sediment depth } \\
(\mathrm{cm})\end{array}$ & $\begin{array}{l}\text { ATP pool specific } \\
\text { activity }\left(\mathrm{nCi} \mathrm{pmol}^{-1}\right)^{a}\end{array}$ & $\begin{array}{c}\text { Adenine uptake } \\
(\% \text { salvage })^{\mathrm{b}}\end{array}$ & $\begin{array}{l}\text { AN pool turnover } \\
\text { (min) }\end{array}$ & $\begin{array}{c}\text { Community doubling } \\
\text { t.me (h) }\end{array}$ \\
\hline Interface & $3.08 \pm 0.25$ & 20.5 & $39.0 \pm 6.2$ & 26.0 \\
\hline $0-1$ & $4.89 \pm 0.32$ & 32.6 & $71.9=9.7$ & 47.9 \\
\hline $1-2$ & $4.70 \pm 0.31$ & 31.4 & $74.4 \pm 0.6$ & 49.6 \\
\hline $2-3$ & $5.80 \pm 0.61$ & 38.7 & $138.4 \pm 30.5$ & 92.3 \\
\hline $3-4$ & $7.27 \pm 0.83$ & 48.5 & $100.5 \pm 29.2$ & 67.0 \\
\hline $4-5$ & $7.92 \pm 0.60$ & 52.8 & $91.3 \pm 18.4$ & 60.9 \\
\hline \multicolumn{5}{|c|}{$\begin{array}{l}\text { a Maximum specific radioactivities determined at isotopic equilibrium. These data were calculated from non-linear least } \\
\text { squares analyses of time course labeling experiments (see Materials and Methods) } \\
\text { " Minimum contribution from salvage uptake of adenine containing compounds calculated from the value measured for the } \\
\text { maximum ATP pool specific radioactivity. Theoretical maximum specific radioactivity is } 15.0 \mathrm{nCi} \mathrm{pmol}^{-1} \text { and is identical to } \\
\text { the value of the added radioisotopic tracer } \\
\text { c Doubling time is extrapolated from adenine nucleotide pool turnover time assuming that the pool turns over } 40 \text { times per } \\
\text { generation (Karl \& Bossard 1985) }\end{array}$} \\
\hline
\end{tabular}

pools of adenine containing compounds, the $S A_{\max }$ value would be identical to the specific radioactivity of the radiotracer (in our case, $15 \mathrm{nCi} \mathrm{pmol}{ }^{-1}$ ). Any deviation from this theoretical maximum value can be interpreted as the effect of de novo synthesis, and differences between depth horizons can be directly related to differences in the ability of the microbial assemblages to salvage nucleic acid precursors. Our results indicate that at a depth of $5 \mathrm{~cm}$, at least $50 \%$ of the adenine incorporated into microbial nucleic acids (and presumably, other nucleic acid precursors not specifically evaluated in this study) was derived from exogenous pools via salvage metabolic pathways. In all likelihood, this percentage is even greater because these conservative estimates assume no dilution of the added radiotracer by exogenous pools of adenine-containing compounds in the diluent medium. These results also indicate that the majority of the viable microorganisms ('ATP-containing') present in Kahana Bay sediments must be capable of assimilating adenine at nanomolar concentrations. If there were a substantial population of viable, but non-responsive cells it would have been impossible to obtain $\mathrm{SA}_{\max }$ values as high as those observed in this study. Furthermore, we must conclude that the majority of microorganisms in Kahana Bay sediment are actively growing because senescent, nongrowing or otherwise debilitated cells do not assimilate ${ }^{3} \mathrm{H}$-adenine (Karl 1979).

\section{DNA: RNA production ratio}

A major difference between pelagic and benthic habitats can be seen in the DNA: RNA synthesis rate ratios. For the Kahana Bay water column, the measured rate of DNA synthesis was $14.8 \%$ of the RNA synthesis rate, a value consistent with data from other diverse pelagic ecosystems (Karl 1981, Burns et al. 1984, Karl \& Knauer 1984, Karl \& Winn 1984, Winn \& Karl 1984). In Kahana Bay sediments, however, the rate of DNA synthesis varied from a minimum of $2 \%$ to a maximum of $4.8 \%$ of the measured rate of RNA synthesis (Fig. 3). Both the low DNA: RNA synthesis rate ratios and the large discrepancy between pelagic and sedimentary ecosystems have been observed (Burns et al. 1984 Craven \& Karl 1984), but have not yet been adequately explained. Karl (1981) has previously indicated that where microbial biomass is in a steady-state, the DNA: RNA production rate ratio would be identical to the DNA - RNA cell quota. The cell quota ratio is highly correlated with growth rate under conditions of asynchronous, balanced growth such that low DNA: RNA ratios $(<10 \%)$ are associated with the most rapid growth rates (Rosset et al. 1966, Dennis \& Bremer 1974, Brunschede et al. 1977, Dortch et al. 1983). The enigma, first pointed out by Craven \& Karl (1984), is that sedimentary populations oftentimes exhibit concurrently low DNA : RNA rate ratios and low specific growth rates. It is obvious that the physiological state of the microorganisms resident in the sedimentary ecosystem can not be compared to that of laboratory-reared populations of bacteria growing exponentially in homogeneous media.

Clearly, the relatively long doubling times measured in the AN pool turnover experiments are inconsistent with the measured DNA: RNA rate ratios, if we interpret the latter within the context of the data base derived from laboratory experiments. We conclude, therefore, that the anomalously low DNA:RNA production ratios measured in Kahana Bay sediments (Fig. 3) are the result of the presence of a microbial assemblage which must maintain a high rate of RNA synthesis relative to that needed for normal cell division. We hypothesize that this metabolic state is the result of either: (1) unbalanced growth (i.e. growth 


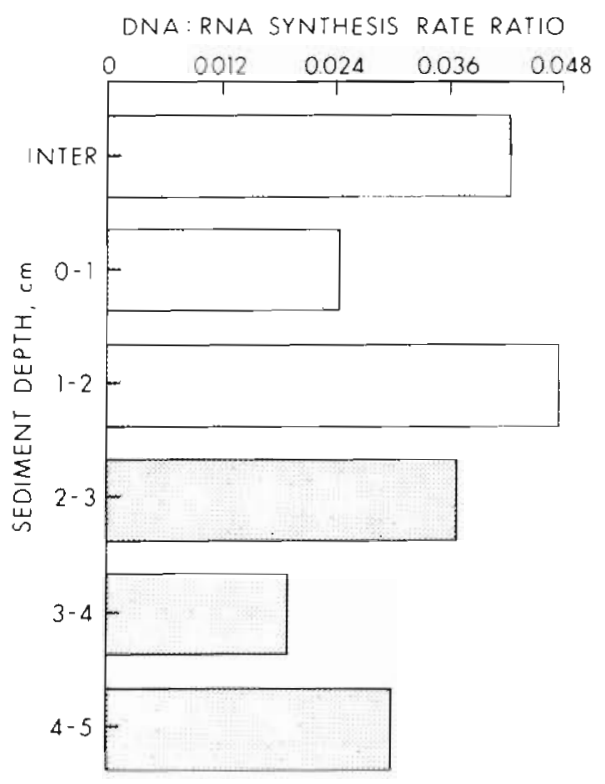

Fig. 3. Sediment depth variation in the ratio of DNA to RNA synthesis for the total microbial communities collected from Kahana Bay, Hawaii. Sample date: 10 Jan 1984

[RNA synthesis] without concomitant cell division [DNA synthesis]) or (2) significant metabolic turnover of cellular RNA in the absence of DNA turnover.

Several environmental conditions unique to the sedimentary habitat could result in the unbalanced growth of the resident microbial assemblage. For example, if a portion of the population were alive but starved, debilitated or otherwise unable to divide (as may be the case for coastal sediments, in general; see Novitsky 1987), the rates of RNA and DNA synthesis might be expected to be uncoupled from the 'expected' cell quota demands. Amy et al. (1983) have reported an initial decrease in cellular RNA and DNA upon the initiation of starvation in a marine bacterium (Vibrio sp., Ant-300), but also observed a post-starvation induction in RNA synthesis without a concomitant increase in the rate of DNA synthesis. An analysis of a microbial population in this metabolic state would yield a result that is consistent with our field data (Fig. 3, Table 2). Koch (1971) has also discussed the presence of 'extra' RNA in slow growing bacteria, A rapidly utilizable pool of cellular RNA may be common within microorganisms that inhabit environments of spatial or temporal nutritional heterogeneity. Koch (1971) argued that such a physiological state should have a great selective value for all microorganisms exposed to a feast or famine mode of existence. Elevated cellular RNA levels at slow growth rates would also allow for substantial starvation-induced RNA degradation to occur, without affecting viability.

The cause of the low DNA: RNA synthesis rate ratios measured in Kahana Bay sediments was evaluated to ascertain whether growth (as measured by net RNA synthesis) and cell division (as measured by DNA synthesis) were coupled in this coastal marine ecosystem. We first had to eliminate the possibility that the low ratios which we observed were caused by either an underestimation of DNA synthesis or an overestimation of RNA synthesis, or a combination of these 2 potential experimental artifacts. Craven \& Karl (1984) have discussed the importance of $\mathrm{pH}$-dependent adenine adsorption/desorption reactions in the analysis of marine sediments. If ${ }^{3} \mathrm{H}$-adenine adsorbed onto sediment particles during the incubation procedure and subsequently desorbed during the alkaline hydrolysis of RNA, the released adenine would not be readily separated from the hydrolytic endproducts. The net result would be an overestimation of 'RNA' and an overestimation of the calculated rate of RNA synthesis. The adsorption-desorption characteristics of a given sediment are best evaluated by direct experimentation. In practice, this evaluation is already integrated into the recommended procedure for 'Type I' sediments (Craven \& Karl 1984), although it was not specifically designed as a quantitative measurement of the potential interference caused by adenine adsorption. A comparison of RNA activity ( $\mathrm{nCi} \mathrm{cm}^{-3}$ of wet sediment) with and without the sediment phase present following alkaline hydrolysis, but before sample acidification, allows one to determine the extent of this potential problem (Craven \& Karl 1984). For Kahana Bay sediments, the ratio of ${ }^{3} \mathrm{H}$-adenine desorption to ${ }^{3} \mathrm{H}$-adenine incorporated into RNA ranged from a minimum of 0.05 at the sedimentseawater interface to a maximum of 0.11 at a depth of $5 \mathrm{~cm}$. This increase with increasing depth is simply a reflection of the fact that total microbial biomass and total metabolic activity decrease with increasing sediment depth; the absolute amount of ${ }^{3} \mathrm{H}$-adenine interference due to adsorption-desorption was relatively constant with depth and reflected the constancy of the chemical composition of the sediments.

Having dismissed the most likely potential artifact in the calculation of DNA: RNA synthesis rate ratios, we can now address the 2 previously mentioned hypotheses. First, it is possible that net RNA synthesis is a small fraction of gross RNA synthesis due to a substantial metabolic turnover of cellular RNA. As an alternate to the unbalanced growth hypothesis, we suggest that microbial growth (as measured by net RNA synthesis) may not be closely coupled in time to cell division (as measured by DNA synthesis). In our short-term radiotracer experiments, we measure a value closer to the gross rate than to net RNA production. In rapidly growing microbial cells the difference between these 2 measurements is negligible, but in extremely slow growing populations (e.g. $\left.\mu / u_{\max } \leq 0.01\right\}$ metabolic turnover of RNA becomes a significant percentage of gross RNA synthesis. Because 
Table 3. Rates of nascent RNA turnover in Kahana Bay sediments

\begin{tabular}{|c|c|c|c|c|c|c|}
\hline \multirow[t]{2}{*}{$\begin{array}{l}\text { Sediment } \\
\text { depth } \\
(\mathrm{cm})\end{array}$} & $\begin{array}{c}\text { Pre-chase } \\
\text { RNA } \\
\text { production }\end{array}$ & $\begin{array}{c}\text { Post-chase } \\
\text { RNA } \\
\text { destruction }\end{array}$ & $\begin{array}{c}\% \\
\text { RNA } \\
\text { turnover }\end{array}$ & $\begin{array}{l}\text { Pre-chase } \\
\quad{ }^{3} \mathrm{H}_{2} \mathrm{O} \\
\text { production }\end{array}$ & $\begin{array}{l}\text { Post-chase } \\
{ }^{3} \mathrm{H}_{2} \mathrm{O} \\
\text { production }\end{array}$ & $\begin{array}{c}\% \\
\text { metabolic } \\
\text { turnover }\end{array}$ \\
\hline & \multicolumn{2}{|c|}{$\left(\mathrm{nCi} \mathrm{g}^{-1}\right.$ sed DW $\left.\mathrm{h}^{-1}\right)$} & \multicolumn{4}{|c|}{$\left(\mathrm{nCi} \mathrm{ml} \mathrm{l}^{-1}\right.$ suspension $\mathrm{h}^{-1}$ ) } \\
\hline Interface & 49599 & 4174 & 8.4 & 521 & 29.5 & 5.7 \\
\hline $0-1$ & 23566 & 1944 & 8.2 & 297 & 14.8 & 5.0 \\
\hline $1-2$ & 18921 & 1166 & 6.2 & 224 & 10.8 & 4.8 \\
\hline $2-3$ & 13151 & 494 & 3.8 & 82.5 & 3.4 & 4.1 \\
\hline $3-4$ & 12885 & 466 & 3.6 & 81.7 & 2.8 & 3.4 \\
\hline $4-5$ & 8805 & 725 & 8.2 & 37.2 & 3.3 & 8.9 \\
\hline
\end{tabular}

DNA is not expected to turn over, even at these relatively slow growth rates, the DNA: RNA synthesis rate ratios estimated by our procedures could underestimate the actual net synthesis rate ratio.

The metabolic turnover of 'stable' RNA and DNA can be measured using a pulse-chase experimental protocol (Karl 1981). In the Kahana Bay sediment experiments, we labeled the resident microbial cells with ${ }^{3} \mathrm{H}$ adenine for a period of $2.5 \mathrm{~h}$ before the addition of a 1000 -fold excess of non-radioactive adenine to eliminate further uptake of the labeled tracer (Fig. 4). During the initial labeling period, ${ }^{3} \mathrm{H}$-adenine uptake and assimilation (as indicated by the rate of ${ }^{3} \mathrm{H}_{2} \mathrm{O}$ production) and incorporation into RNA are linear functions of time. Following the addition of non-radioactive adenine no further metabolism or incorporation of ${ }^{3} \mathrm{H}$ adenine occurs (Karl 1981). Under these conditions, the rate at which radioactivity is removed from the total radioactive RNA pool is a direct measure of the rate of stable RNA turnover (Table 3). The measurement of the post-chase production of ${ }^{3} \mathrm{H}_{2} \mathrm{O}$ (Fig. 4, Table 3) also provides independent evidence for metabolic turnover of stable RNA in the absence of ${ }^{3} \mathrm{H}$-adenine uptake. Our pulse-chase results indicate that the rate of metabolic turnover of stable RNA amounts to less than $10 \%$ of the total rate of incorporation (range 3.6 to 8.4 ), and displays no systematic variation with sediment depth (Table 3). The ratio of the rate of post-chase ${ }^{3} \mathrm{H}_{2} \mathrm{O}$ production to the pre-chase rate ranged from 3.4 to $8.9 \%$ and was consistent with the data for the metabolic turnover of RNA (Table 3 ). These independent results on adenine metabolism add further support to the conclusion that net RNA synthesis must be most (i.e. $\geq 90 \%$ ) of the total RNA synthesis measured in our experiments. This indicates that net RNA synthesis, for the purpose of this discussion, is equal to gross RNA synthesis. Thus we conclude that the sedimentary microbial populations must maintain high rates of RNA synthesis, relative to their rates of DNA synthesis, in spite of relatively slow growth rates.

In summary, we suggest that the microbial communities in Kahana Bay sediments are metabolically active assemblages of cells which exhibit net growth, carbon production and cell division, at least to a depth of $5 \mathrm{~cm}$. Our field data provide support for the hypothesis that cell growth and cell division are uncoupled, over the time scales investigated (hours to days). In this regard, our study site may be viewed as being analogous to the recently described Quiambog Cove ecosystem (Matson \& Buck 1987) for which the authors conclude that sediment heterogeneity maintains a metabolic diversity throughout the year. For Kahana Bay sediments, we cannot be certain whether the growth of microorganisms is continuous or discontinuous, but it does appear to be unbalanced. The factors controlling the growth and reproduction of microbial sediment communities are largely unknown but probably many and varied. Factors leading to unbalanced growth would possibly include stochastic phenomena such as nutrient input influenced by storm events, tides, river runoff, etc., and periodic physical or biological disturbance of the top layers of sediment.

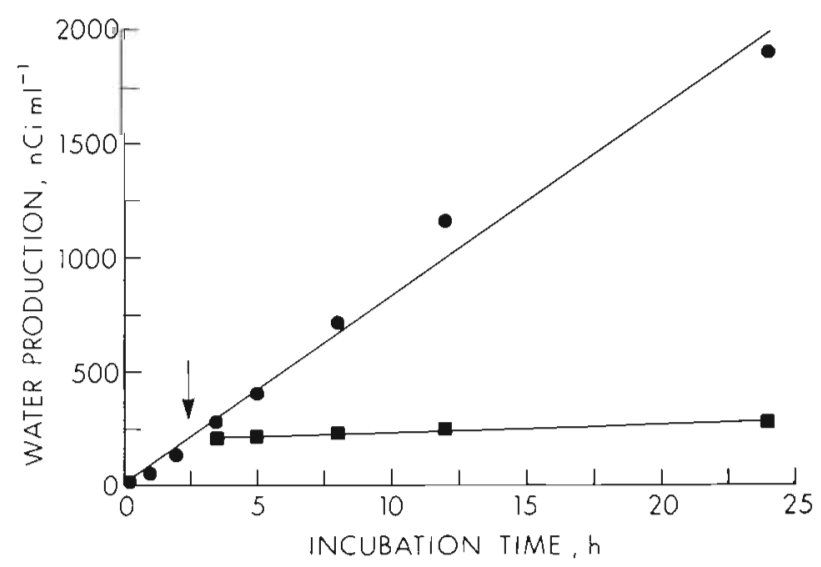

Fig. 4. Representative time course of tritiated water accumulation following the addition of ${ }^{3} \mathrm{H}$-adenine to a Kahana Bay sediment sample. Data from 2 to $3 \mathrm{~cm}$ depth, collected on $10 \mathrm{Jan}$ 1984. Linear production of ${ }^{3} \mathrm{H}_{2} \mathrm{O}$ for the pulse (control) sample; ( $)$ replicate chase treatment which received a 1000-fold excess of non-radioactive adenine at $2.5 \mathrm{~h}$ into the incubation period (arrow). Equations for the 2 curves are: $\mathrm{Y}=$ $9.4+82.5 \mathrm{x}$ (pulse); $\mathrm{Y}=200+3.45 \mathrm{x}$ (chase) 
Because our present state of knowledge is insufficient, extrapolation of the marine sedimentary field data or its use in model construction must be approached with extreme caution.

Acknowledgements. The authors thank Jean Novitsky and Ursula Magaard for assistance in sampling and analysis; D. Bird, G. Tien and C. Winn, for constructive criticism of a preliminary draft; and Lisa Wong, for assistance in the preparation of this manuscript. This research was supported, in part, by grant OCE83-51751 from the Biological Oceanography section of the National Science Foundation and Grants A-6548 and T-1925 from the National Research Council of Canada. Contribution \#2055 of the Hawaii Institute of Geophysics.

\section{LITERATURE CITED}

Amy, P. S., Pauling, C., Morita, R. R. (1983). Starvationsurvival processes of a marine vibrio. Appl environ. Microbiol 45: 1041-1048

Brunschede, H., Dove, T L., Bremer, H. (1977). Establishment of exponential growth after a nutritional shift-up in Escherichia coli B/r: accumulation of deoxyribonucleic acid, ribonucleic acid and protein. J. Bact. 129: 1020-1033

Burns, D., Andrews, C., Craven, D., Orrett, K., Pierce, B., Karl, D. (1984). Microbial biomass, rates of DNA synthesis and estimated carbon production in Kaneohe Bay, Hawaii. Bull. mar. Sci. 34: 346-357

Craven, D. B., Jahnke, R. A., Carlucci, A. F. (1986). Fine-scale vertical distributions of microbial biomass and activity in California Borderland sediments. Deep Sea Res. 33: 379-390

Craven, D. B., Karl, D. M. (1984). Microbial RNA and DNA synthesis in marine sediments. Mar. Biol. 83: 129-139

Dennis, P. P., Bremer, H. (1974). Macromolecular composition during steady-state growth of Escherichia coli B/r. J. Bact. 119: $270-281$

Dortch, Q., Roberts, T L., Clayton, J. R., Ahmed, S. I. (1983). RNA/DNA ratios and DNA concentrations as indicators of growth rate and biomass in planktonic marine organisms. Mar Ecol. Prog. Ser 13: 61-71

Douglas, D. J., Novitsky, J. A., Fournier, R. O. (1987). Microautoradiography-based enumeration of bacteria with estimates of thymidine-specific growth and production rates. Mar Ecol. Prog. Ser. 36: 91-99

Fallon, R. D., Newell, S. Y., Hopkinson, C. S. (1983). Bacterial production in marine sediments: will cell-specific measures agree with whole-system metabolism? Mar Ecol. Prog. Ser 11. 119-127

Karl, D. M. (1979). Measurement of microbial activity and growth in the ocean by rates of stable ribonucleic acid synthesis. Appl. environ. Microbiol. 38: 850-860

Karl, D. M. (1981). Simultaneous rates of ribonucleic acid and deoxyribonucleic acid syntheses for estimaing growth and cell division of aquatic microbial communities. Appl. environ. Microbiol. 42: 802-810

Karl, D. M. (1986). Determination of in situ microbial biomass, viability, metabolism, and growth. In: Poindexter, J. S., Leadbetter, E. R. (eds.) Bacteria in nature, Vol. 2. Plenum Publishing Corporation, p. 85-176
Karl, D. M. Bossard, P. (1985). Measurement and significance of ATP and adenine nucleotide pool turnover in microbial cells and environmental samples. J. Microbiol. Meth. 3: 125-139

Karl, D. M. Craven, D. B. (1980). Effects of alkalıne phosphatase activity on nucleotide measurements in aquatic microbial communities. Appl. environ. Microbiol. 40: 549-561.

Karl, D. M., Jones, D. R., Novitsky, J. A., Winn, C. D., Bossard, P. (1987). Specific growth rates of natural microbial communities measured by adenine nucleotide pool turnover. J. Microbiol. Meth. 6: 221-235

Karl, D. M., Knauer, G. A. (1984). Vertical distribution, transport, and exchange of carbon in the northeast Pacific Ocean: evidence for multiple zones of biological activity. Deep Sea Res. 31 221-243

Karl, D. M., Winn, C. D. (1984). Adenine metabolism and nucleic acid synthesis: applications to microbial oceanography. In: Hobbie, J. E., Williams, P. J. LeB. (eds.) Heterotrophic activity in the sea. Plenum Publishing Corporation, New York, p. 197-215

Koch, A. L. (1971). The adaptive responses of Escherichia coli to a feast and famine existence. Adv. Microb. Physiol. 6: $147-217$

Matson, E. A., Buck, J. D. (1987). Community electron transport of procaryotes in euryoxic estuarine sediment. Mar. Ecol. Prog. Ser. 41.71-78

Meyer-Reil, L.-A., Bolter, M., Dawson, R., Liebezeit, G., Szwerinski, H., Wolter, K. (1980). Interrelationships between microbiological and chemical parameters of sandy beach sediments, a summer aspect. Appl. environ. Microbiol. 39: 797-802

Newell, S. Y., Fallon, R. D. (1982). Bacterial productivity in the water column and sediments of the Georgia (USA) coastal zone: estimates via direct counting and parallel measurement of thymidine incorporation. Microb. Ecol. 8: 33-46

Novitsky, J. A. (1983a). Heterotrophic activity throughout a vertical profile of seawater and sediment in Halifax Harbor, Canada. Appl. environ. Microbiol. 45: 1753-1760

Novitsky, J. A. (1983b). Microbial activity at the sedimentwater interface in Halifax Harbor, Canada. Appl environ. Microbiol. 45: 1761-1766

Novitsky, J. A. (1987). Microbial growth rates and biomass production in a marine sediment: evidence for a very active but mostly nongrowing community. Appl. environ. Microbiol. 53: 2368-2372

Novitsky, J. A., Karl, D. M. (1986). Characterization of microbial activity in the surface layers of a coastal sub-tropical sediment. Mar. Ecol. Prog. Ser. 28: 49-55

Rosset, R, Julien, J., Monier, R. (1966). Ribonucleic acid composition of bacteria as a function of growth rate. J. Molec Biol. 18: 308-320

Rublee, P. A. (1982). Bacterial and microbial distribution in estuarine sediments. In: Kennedy, V. (ed.) Estuarine comparisons. Academic Press, New York, p. 159-182

Rublee, P. A., Merkel, S. M. Faust, M. A. (1983). The transport of bacteria in the sediments of a temperate marsh. Estuar Coast. Shelf Sci. 16: 501-509

Schroder, H. G. J., Van Es, F. B. (1980). Distribution of bacteria in intertidal sediments of the Ems-Dollart estuary. Neth. J. Sea Res 14: 268-287

Winn, C. D., Karl, D. M. (1984). Laboratory calibrations of the $\left[{ }^{3} \mathrm{H}\right.$ ] adenine technique for measuring rates of RNA and DNA synthesis in marine microorganisms. Appl. environ Microbiol. 47:835-842 